\title{
CLINICAL SIGNIFICANCE OF HISTOCHEMICAL EXPRESSION OF MUCINS IN COLORECTAL ADENOCARCINOMA
}

\author{
Nina S. Jančići ${ }^{1}$ Janko T. Žujović2, Ivan B.Rančići, Miljan S. Krstić3, \\ Filip C. Vukmirovićt, Velimir S. Milošević
}

\begin{abstract}
Colorectal carcinoma is the most common malignant tumor of the gastrointestinal tract. In the course of colorectal carcinogenesis, in addition to uncontrolled cell proliferation and accelerated angiogenesis, alterations occur in the structure and/or quantity of epithelial mucins, so the aim of our study was to investigate the histochemical expression of mucins in relation to the clinical characteristics of colorectal carcinoma.

The biopsy material of 75 patients operated from colorectal carcinoma, which was routinely processed and molded into paraffin, was used for the examination. On 3-4 $\mu \mathrm{m}$ thick cuts, routine H\&E and histochemical AB-PAS pH 2.5 and HID-AB methods were applied. For the statistical analysis, the statistical software package SPSS (version 13) was used.

Mucin alterations occur in colorectal carcinoma and manifest themselves as a trace to moderate secretions of neutral or fucomucins, moderate to hypersecretions of sialomucins and trace to complete secretions of sulfomucins. The fucomucin and sialomucin secretion is associated with a strong, significant and positive coefficient of correlation with the Astler-Coller classification of the tumor stages, with metastases in the lymph nodes and with distant metastases. Unlike fucomucins, sialomucins are associated with a strong, positive, significant coefficient of correlation with the pathological stage of the tumor. Sulfomucins are associated with the significant, but negative coefficients of correlation with the tumor pathological stage, tumor stages according to the Astler-Coller classification, and metastases in the lymph nodes. The secretions of fucomucins and sialomucins are in a good and significant mutual relationship, only the secretion of sulfomucins is in a negative correlation in comparison to the other mucins.

Histochemical expression of mucins may be a useful prognostic indicator of the progression of colorectal carcinoma.
\end{abstract}

Acta Medica Medianae 2019;58(3):49-59.

Key words: colorectal carcinoma, epithelial mucins, histochemistry

${ }^{1}$ University of Niš, Faculty of Medicine Niš Serbia

${ }^{2}$ Center for Abdominal Surgery, Clinical Center of Montenegro,

Podgorica, Montenegro

${ }^{3}$ University of Niš, Faculty of Medicine, Department of

Pathology, Niš, Serbia

${ }^{4}$ Department of Pathology Clinical Center of Montenegro, Podgorica, Montenegro

${ }^{5}$ Department of Gastroenterology and Hepatology, Clinical

Center of Montenegro, Podgorica, Montenegro

Contact: Velimir S. Milošević

Ljubljanska Street 1, 20000 Podgorica, Montenegro

E-mail: vejja@t-com.me plasms in human oncology (1). Alarming is the fact that the incidence and mortality in the last three decades have been rising steadily with an average annual growth rate of around $3 \%$ or with more than 400,000 newly diseased during a year. A striking increase in the incidence has been recorded in transition countries and in Australia/New Zealand, Europe and North America (2). In Serbia, colorectal carcinoma is the second leading cause of death with a mortality rate of $16.6 / 100.000$, on the basis of which Serbia is ranked among the countries with high mortality (3).

Colorectal carcinoma is a multifactorial disease resulting from the interaction of hereditary factors and environmental factors $(4,5,6)$. The risk for the development of colorectal carcinoma rises significantly after 40 years of age, and about $85 \%$ of colorectal carcinoma occurs in people older than 50 years of age (7). The risk of colorectal carcinoma has been estimated to be 15 times higher in people over 50 years of age than in people aged 20-49 years (8). cinoma (IARC) has classified colorectal carcinoma among the three most frequent malignant neo- 
Based on molecular and cytogenetic studies, it has been established that colorectal carcinoma develops in one of two genetic pathways. The first is the pathway of chromosomal instability or the APC/ $\beta$-catenin pathway, known as the "adenoma-carcinoma" sequence, and the second is the pathway of microsatellite instability or correction of the wrongly paired DNA (9). During colorectal carcinogenesis, in addition to the uncontrolled cell proliferation and accelerated angiogenesis, alterations in the structure and/or quantity of epithelial mucins with subsequent changes in the mucus protective function and cell signal transduction disorders occur $(10,11)$. These changes in the expression of mucins or glycosylation affect cell growth, differentiation, transformation, adhesion, invasiveness, and immune control of the tumor (12).

\section{Aim of the study}

The aim of our study was to examine the histochemical expression of epithelial mucins in relation to the clinical characteristics of colorectal carcinoma.

\section{Materials and methods}

\section{Patients and samples}

The study included 75 patients with colorectal adenocarcinoma, who underwent the surgical resection of the tumor in the Center for Abdominal Surgery of the Clinical Center of Montenegro (KCCG). In the Institute of Pathology of CCCG, from each operative resection, depending on the size of the tumor, 5-15 biopsies were taken, including 2-3 biopsies of the surrounding healthy tissue of the colon. After the fixation in a $4 \%$ buffered formaldehyde solution, the biopsy material was routinely processed, molded into paraffin blocks and archived.

Tumors tissue samples of colorectal carcinomamade up the study (experimental) group $(n=75)$. The control group ( $n=75$ ) consisted of opera-tive biopsies of adjacent non-tumor tissue of the colon, which were taken from the operative preparation according to the protocol.

This research was carried out in conjunction with the Helsinki Declaration and the World Health Organization's Recommendations for experiments on human material. The consent of the supervisory Ethics Committee exists for the research.

\section{Histopathology and mucin histochemistry}

Serial cuts, 3-4 $\mu \mathrm{m}$ thick, have been made from paraffin blocks of all resected tumors and regional lymph nodes, on which routine HematoxylinEosin method, for histopathological verification of lesions, histochemical AB-PAS pH 2.5 (Alcian BluePeriodic Acid Schiff) method, for the differentiation of neutral from acidic mucins, and histochemical HID-AB pH 2.5 (High Iron Diamine-Alcian Blue) technique, for the differentiation of weak acidic, unsulphated sialomucins from strong acidic, sulphatedsulfomucins, was applied.
Histochemical expression of epithelial mucins has been quantified according to the following scale: - (minus), mucins asecretion; +/- (plus minus), trace secretion of mucins; + (1 plus), moderate secre-tion of mucins; ++ (2 pluses), strongly expressed secretion (hypersecretion) of mucins.

\section{Statistical analysis}

For the statistical analysis of the obtained results, the statistical software package SPSS (version 13.0) has been used. The $\chi^{2}$-test (chi-squared test), Mann-Whitney $U$ test, Kruskal-Wallis test and Student's t-test have been used to analyze the significance of the differences between parametric and non-parametric features between and within the groups. Then, the Kolmogorov-Smirnov test for the normality of distribution, the univariate statistical analysis, the correlation analysis (Spearman's coefficient of rank correlation, Pearson's correlation coefficient for parametric features) have been used. Significance testing has been performed at $p<0.05$.

\section{Results}

In the examined sample of patients, in whom the colorectal carcinoma was removed, there were 45 men (60\%) and 30 women (40\%). There is no statistically significant difference in the presence of colorectal carcinoma in relation to the gender of the patients, at the adopted level of reliability $p<0.05$ $\left(\chi^{2}\right.$-test $\left.=3.000 ; p=0.083>0.05\right)$.

There was also no statistically significant difference between the groups, by the age of the patients (Mann-Whitney $\mathrm{U}$ test $=569.500 ; \mathrm{p}=0.232$ ). Male patients had an average age of $65.9 \pm 10.8$ years and women $60.8 \pm 14.5$ years, which was not a significant difference (Student's t-test $=1.622 ; \mathrm{p}$ $=0.111$ ).

In the examined sample of patients, the most frequent localisation of the carcinoma was in the rectum. The frequency of this localisation with $65.3 \%$ of the cases was highly statistically significant $\left(\chi^{2}\right.$-test $\left.=7.053 ; p=0.008\right)$, compared to all other localisations in the colon.

There was no statistically significant difference in the distribution of colorectal carcinomas with respect to the macroscopic type of the tumor (from $26.7 \%$ to $37.3 \%$ ), but it was noticed that the most commonly occurring type was the ulceroinfil-trative type (37.2\% of the cases).

The greatest number of the examined cases $(74.7 \%)$ of colorectal adenocarcinoma were diagnosed in the third stage according to the pathological classification (pT3), which significantly differed from the number of cases diagnosed as stage pT2 $(16 \%)$. Colorectal carcinoma rarely occurs in the lowest and highest PT stage $(2.7 \%$ and $6.7 \%$ of the cases).

The distribution of the examined colorectal carcinoma in relation to the Astler-Coller classification showed the lowest frequency of tumors in the C1 stage (one case, 1.3\%) and the D stage (7 patients, $9.3 \%)$. This frequency was followed by the 
B1 stage (11 cases, 14.7\%). The highest frequency of patients was in the B2 stage (25 patients, 33.3\%) and the C2 stage (31 cases, $41.3 \%$ ).

Metastases in lymph nodes were found in 39 patients $(52 \%)$, while in 36 patients $(48 \%)$ metastases were not found in the lymph nodes. Metastatic deposits in 1-3 lymph nodes were found in 22 patients $(29.3 \%)$, deposits in 4-6 lymph nodes were found in 8 patients $(10.7 \%)$, and in 9 patients (12\%) deposits were present in more than 7 lymph nodes (Graph 2). Distant metastases were found in $10.7 \%$ of the patients.

By examining the histochemical expression of neutral mucins (fucomucins) in the non-tumor tissue, in $97.3 \%$ of the cases, their complete asecretion was noticed, which was an obvious significance that did not need to be statistically proven. In the colorectal adenocarcinoma tissue of $48 \%$ of the cases, the fucomucine asecretion was verified, in
$45.3 \%$ of the cases there was a trace secretion present, and in $6.7 \%$ of the cases, a moderate secretion of neutral mucins was found (Graph 1).

In the control group (non-tumor tissue), in a significant number of cases, the most common finding was the trace secretion of sialomucins $\left(68 \% ; \chi^{2}-\right.$ test $=9.720 ; p=0.002)$. The frequency of asecretion (18.7\%) or moderate secretion (12\%) of sialomucins in this group, was significantly less common and without significant statistical difference. The occurrence of sialomucin hypersecretion in nontumor surrounding tissue was extremely rare $(1.3 \%$ of the cases). In contrast to this distribution, in colorectal adenocarcinoma of $42.7 \%$ of the cases hypersecretion of sialomucins was found (Figure 1), moderate secretion in $45.3 \%$, trace secretion in $12 \%$ of the cases, and in no case the asecretion of sialomucins was found (Graph 2).

\section{FUCOMUCINS}

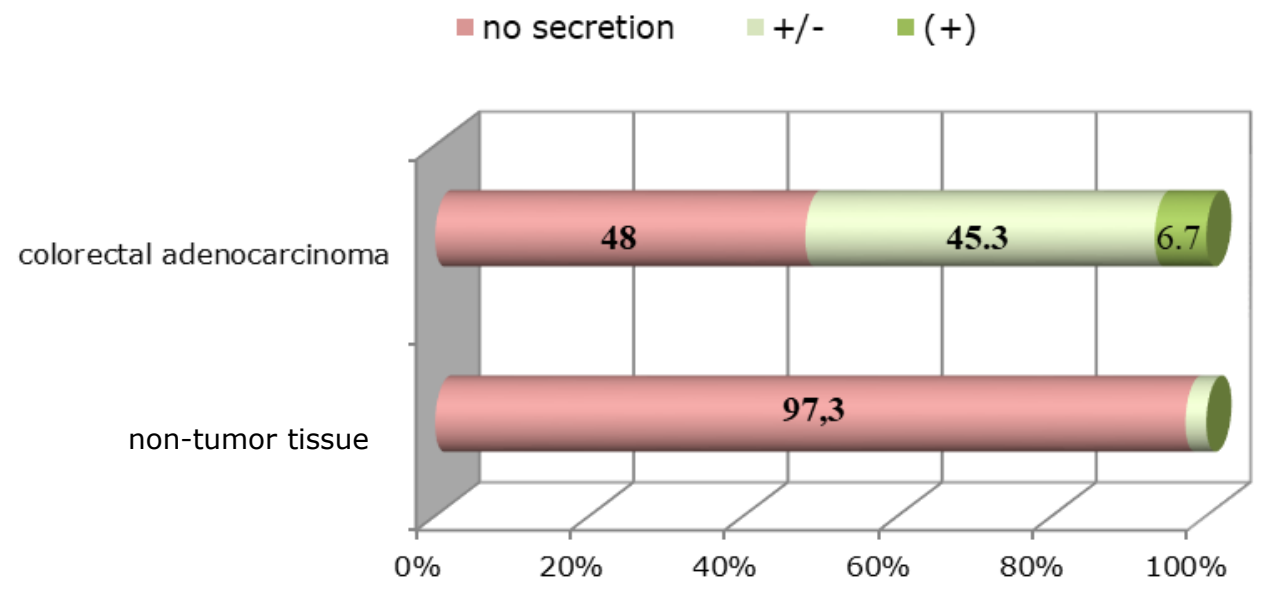

Graph 1. Distribution of neutral - fucomucins in colorectal carcinoma and adjacentnon-tumoral tissue

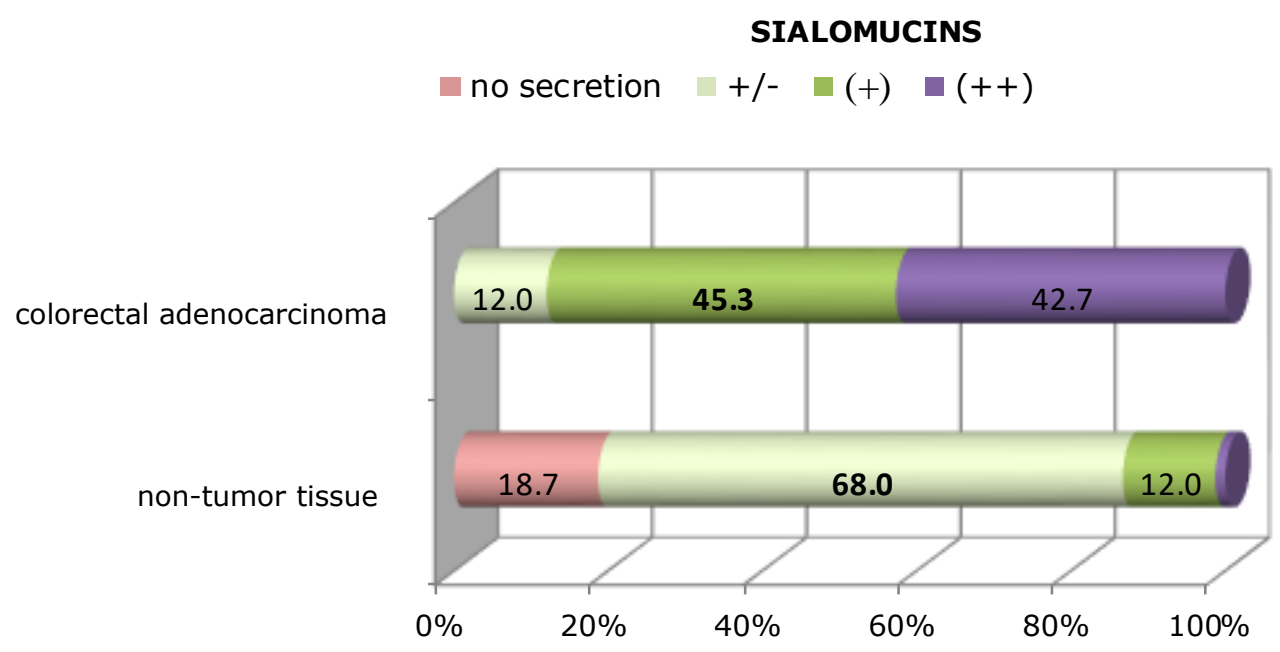

Graph 2. Distribution of poorly acidic - sialomucins in colorectal carcinoma and adjacent non-tumor tissue 


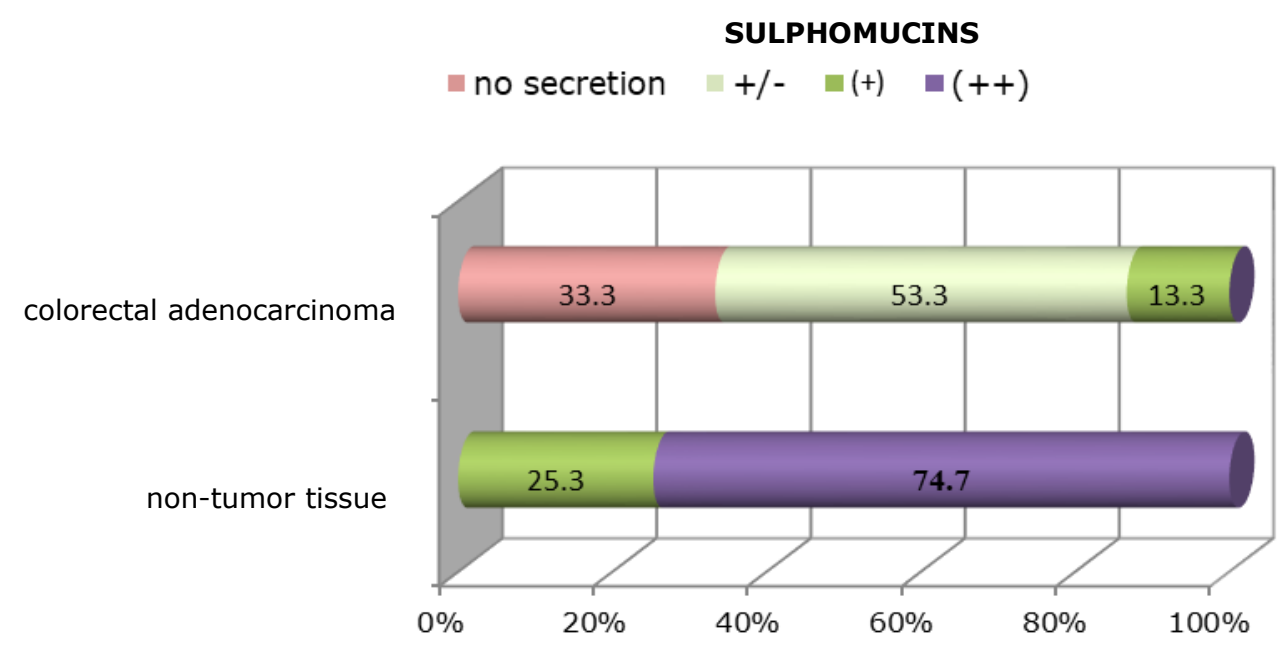

Graph 3. Distribution of highly acidic - sulfomucins in colorectal carcinoma and adjacent non-tumor tissue

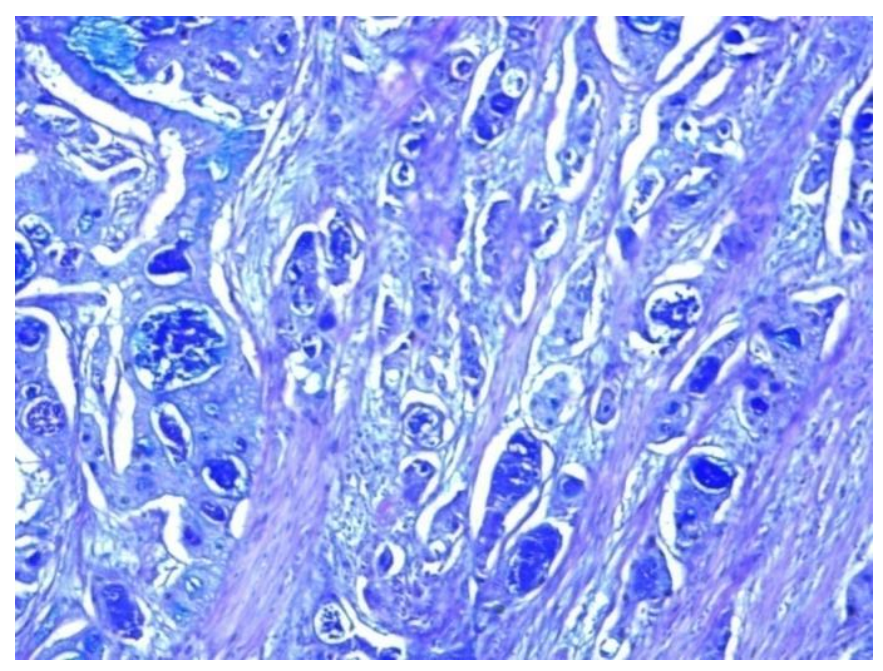

Figure 1. Pronounced histochemical expression of sialomucins in colorectal carcinoma

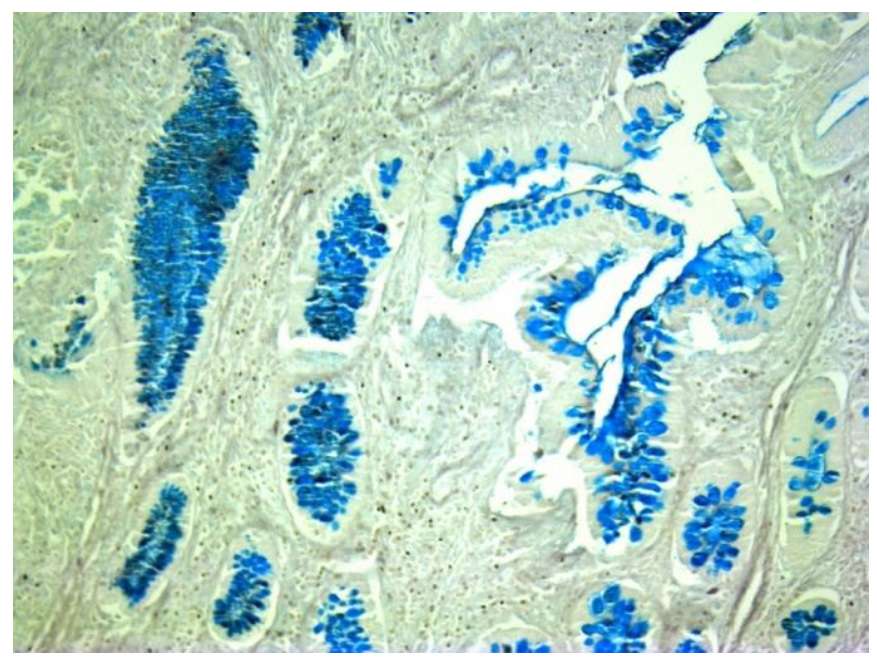

Figure2. Excessive sulfomucins reduction (black) and hypersecretion of sialomucins in colorectal carcinoma (HID-AB x200). 
By analyzing the non-tumor tissue, significant hypersecretion (74.7\%) of strong acidic sulphomucins was observed, which is a statistical significance that should not be specifically proven. Only in about $25.3 \%$ of the cases a moderate secretion was found, while trace secretion and asecretion of sulphomucins were not detected in this group of subjects.Contrary to this finding, in the colorectal adenocarcinoma group, hypersecretion of sulphomu-cins was not identified in any case, and moderate secretion was a significantly rare occurrence $(13.3 \%)$ compared to the remaining cases. In most of the remaining cases, the trace secretion of sulphomucins (53.3\% of the cases) (Figure 2), or the complete asecretion of mucins (33.3\% of the cases) was found (Graph 3 ).

The connection of the mucin secretion with the clinical parameters of colorectal carcinoma

By examining the mucin secretion in relation to the gender and age of patients and by testing the significance (Mann-Whitney $U$ test), no statistically significant differences were found in either parameter (fuco-, sialo-, and sulphomucins) between the comparable gender and age groups.

No statistically significant difference in the expression of mucins (fuco-, sial- and sulphomucins) (Kruskal-Wallis test; $p=0.212$ to $p=0.833$ ) was found compared to the macroscopic type of tumor.

Mucin expression in relation to colorectal carcinoma localisation also did not show statistically significant differences (Kruskal-Wallis test; $p=0.212$ to $\mathrm{p}=0.833$ ).

The distribution of all the analysed mucins in relation to the pathological stage of the tumor (pT) showed a change in the secretion from the second (pT2) to the third (pT3) pathological stage in the following manner: the secretion of neutral-fucomucins and weak acidic sialomucins increased significantly ( $p=0.008$ and $p=0.001$ ) and of strong acidic-sulphomucins decreased significantly ( $p=0.003$ ). The described mucin secretion trend was also observed in the highest pathological stage of the carcinoma, but due to the low number of data (5 cases), was not the subject of statistical comparison (Table 1).

Mucin expression in relation to the Astler-Coller tumor stage is shown in Table 2. It was noticed that mucin secretion, picturesquely divided the stages according to the Astler Coller classification into two parts, wherein the mucine secretion parameters were arranged in a similar manner in stages B1 and $B 2$ versus stages $C 1$ to $D$. It was also observed that the expressions of mucins within the B1 and B2 groups, but also within the $C 1$ to $D$ groups, were statistically indifferent (Mann-Whitney $U$ test for B1$B 2 ; p=0.074$ to $p=0.839$ and $C 1$ to $D ; p=0.053$ to $p=0.658)$. However, when the whole group B1B2 was compared with the C1-D group, a highly significant difference in the expression of mucins ( $p$ $<0.0001$ ) was obtained.

The trend of the distribution of neutral-fucomucins was such that at the B1 and B2 stage the frequency of the cases with increased secretion increased, but it was still similar. However, it was noticed that there was no significant difference be- tween the high frequency of the cases without the secretion of neutral mucins in stage B1 (81.8\%) and $64 \%$ of the cases in stage B2. A significant increase in trace fucomucins occured in C2 stage (67.7\%) and continued in stage $D$ with the occurrence of cases with moderate secretion of this mucin (42.9\%). The trend of the increase of the secretion of neutral mucins followed an increase in the Astler Coller stage $\left(\chi^{2}\right.$-test $\left.=5.444 ; p=0.020\right)$.

By examining the expression of weak acidicsialomucins in relation to the Astler Coller Stages, it was observed that the trace presence of this mucin in the B1 and B2 stage (36.4\% and 12\%) linearly increasesed by the intensity of the secretion up to the hypersecretion that prevailed in the C2 stage and especially in the D stage $(61.3 \%$ and $71.4 \%$ of the cases, respectively), while $C 2$ and D stage trace secretion was extremely rare $(6.5 \%$ and $0 \%$ respectively).

Asecretion of the strong acidic-sulphomucins was a rare occurrence in stages B1 and B2 (0\% and $16 \%)$, as opposed to $C 2$ and D stages, where there was no secretion of this mucins in $58.1 \%$ and $42.9 \%$ of the cases. The trace secretion of sulphomucins did not differ significantly relative to the tumor stage $\left(\chi^{2}\right.$-test $\left.=0.900 ; p=0.343\right)$. Moderate secretion of strong acidic mucins was a more frequent occurrence in stage $\mathrm{B} 1(45.5 \%)$, while it was significantly rarer in higher stages (16\% in B2, $0 \%$ in C2 and $14.3 \%$ in D). ( $\chi^{2}$-test $\left.=11.560 ; p=0.001\right)$.

Examination of mucin secretion in relation to the occurrence of metastases in the lymph nodes and in relation to the number of affected lymph nodes showed that groups, classified by metastases in the lymph nodes, were significantly different only in relation to the cases without metastases (Table 3).

A group of the cases without metastatic deposits was significantly different in the distribution of mucins in relation to the each individual group with a presence of deposits in the lymph nodes. (KruskalWallis test; $p<0.001$ to $p<0.007)$. When the distribution of mucin secretion was considered within the groups without metastases, it was noticed that the absence of deposits in the lymph nodes was approaching the distribution of mucins according to the characteristics of normal colorectal tissue because it did not deviate much from the normal tissue.

The occurrence of metastases in the lymph nodes significantly changed the secretion of the mucins, increasing the intensity of fucomucins and sialomucins secretion with the increase in the number of affected nodes, while the secretion of sulphomucins was decreasing. However, these changes in the secretion of mucins did not show a significant difference between the groups with deposits. That is, the groups of lymph nodes with metastatic deposites did not significantly differ between themselves in relation to mucin expression (Kruskal-Wallis test; $\mathrm{p}=$ 0.119 to $p=0.755)$. 
Table 1. Distribution of mucin secretion in relation to the pathological stage of the tumor

\begin{tabular}{|c|c|c|c|c|c|c|c|c|}
\hline \multirow{3}{*}{$\begin{array}{l}\text { Parameters } \\
\text { FUCOMUCINS }\end{array}$} & \multicolumn{8}{|c|}{ Pathological stage of the tumor } \\
\hline & \multicolumn{2}{|c|}{ Stage I } & \multicolumn{2}{|c|}{ Stage II } & \multicolumn{2}{|c|}{ Stage III } & \multicolumn{2}{|c|}{ Stage IV } \\
\hline & $\mathrm{n}$ & $\%$ & $\mathrm{n}$ & $\%$ & $\mathrm{n}$ & $\%$ & $\mathrm{n}$ & $\%$ \\
\hline No secretion & 1 & 50.0 & 10 & 83.3 & 23 & 41.1 & 2 & 40.0 \\
\hline$+/-$ & 0 & 0.0 & 2 & 16.7 & 29 & 51.8 & 3 & 60.0 \\
\hline$(+)$ & 1 & 50.0 & 0 & 0.0 & 4 & 7.1 & 0 & 0.0 \\
\hline SIALOMUCINS & $\mathrm{n}$ & $\%$ & $\mathrm{n}$ & $\%$ & $\mathrm{n}$ & $\%$ & $\mathrm{n}$ & $\%$ \\
\hline $\begin{array}{l}+/- \\
(+) \\
(++)\end{array}$ & $\begin{array}{l}0 \\
1 \\
1\end{array}$ & $\begin{array}{c}0.0 \\
50.0 \\
50.0\end{array}$ & $\begin{array}{l}4 \\
8 \\
0\end{array}$ & $\begin{array}{c}33.3 \\
66.7 \\
0.0\end{array}$ & $\begin{array}{c}5 \\
23 \\
28\end{array}$ & $\begin{array}{c}8.9 \\
41.1 \\
50.0\end{array}$ & $\begin{array}{l}0 \\
2 \\
3\end{array}$ & $\begin{array}{c}0.0 \\
40.0 \\
60.0\end{array}$ \\
\hline SULFOMUCINS & $\mathrm{n}$ & $\%$ & $\mathrm{n}$ & $\%$ & $\mathrm{n}$ & $\%$ & $\mathrm{n}$ & $\%$ \\
\hline No secretion & 0 & 0.0 & 0 & 0.0 & 21 & 37.5 & 4 & 80.0 \\
\hline $\begin{array}{l}+/- \\
(+)\end{array}$ & $\begin{array}{l}1 \\
1\end{array}$ & $\begin{array}{l}50.0 \\
50.0\end{array}$ & $\begin{array}{l}8 \\
4\end{array}$ & $\begin{array}{l}\mathbf{6 6 . 7} \\
33.3\end{array}$ & $\begin{array}{c}30 \\
5\end{array}$ & $\begin{array}{c}53.6 \\
8.9\end{array}$ & $\begin{array}{l}1 \\
0\end{array}$ & $\begin{array}{c}20.0 \\
0.0\end{array}$ \\
\hline
\end{tabular}

Table 2. Distribution of mucin secretion according to Astler-Coller tumor classification

\begin{tabular}{|c|c|c|c|c|c|c|c|c|c|c|}
\hline \multirow{3}{*}{$\begin{array}{c}\text { Parameters } \\
\text { FUCOMUCINS } \\
\end{array}$} & \multicolumn{10}{|c|}{ Astler-Collerstage of the tumor } \\
\hline & \multicolumn{2}{|c|}{ B1 } & \multicolumn{2}{|c|}{ B2 } & \multicolumn{2}{|c|}{ C1 } & \multicolumn{2}{|c|}{$\mathrm{C} 2$} & \multicolumn{2}{|c|}{ D } \\
\hline & $\bar{n}$ & $\%$ & $\mathrm{n}$ & $\%$ & $\bar{n}$ & $\%$ & $\bar{n}$ & $\%$ & $\bar{n}$ & $\%$ \\
\hline No secretion & 9 & 81.8 & 16 & 64.0 & 0 & 0.0 & 10 & 32.3 & 1 & 14.3 \\
\hline$+/-$ & 1 & 9.1 & 8 & 32.0 & 1 & 100.0 & 21 & 67.7 & 3 & 42.9 \\
\hline$(+)$ & 1 & 9.1 & 1 & 4.0 & 0 & 0.0 & 0 & 0.0 & 3 & 42.9 \\
\hline SIALOMUCINS & $\mathrm{n}$ & $\%$ & $\mathrm{n}$ & $\%$ & $\mathrm{n}$ & $\%$ & $\mathrm{n}$ & $\%$ & $\mathrm{n}$ & $\%$ \\
\hline $\begin{array}{l}+/- \\
(+)\end{array}$ & $\begin{array}{l}4 \\
6\end{array}$ & $\begin{array}{l}36.4 \\
54.5\end{array}$ & $\begin{array}{c}3 \\
16\end{array}$ & $\begin{array}{l}12.0 \\
64.0\end{array}$ & $\begin{array}{l}0 \\
0\end{array}$ & $\begin{array}{l}0.0 \\
0.0\end{array}$ & $\begin{array}{c}2 \\
10\end{array}$ & $\begin{array}{c}6.5 \\
32.3\end{array}$ & $\begin{array}{l}0 \\
2\end{array}$ & $\begin{array}{c}0.0 \\
28.6\end{array}$ \\
\hline$(++)$ & 1 & 9.1 & 6 & 24.0 & 1 & 100.0 & 19 & 61.3 & 5 & 71.4 \\
\hline SULFOMUCINS & $\mathrm{n}$ & $\%$ & $\mathrm{n}$ & $\%$ & $\mathrm{n}$ & $\%$ & $\mathrm{n}$ & $\%$ & $\mathrm{n}$ & $\%$ \\
\hline No secretion & 0 & 0.0 & 4 & 16.0 & 0 & 0.0 & 18 & 58.1 & 3 & 42.9 \\
\hline $\begin{array}{l}+/- \\
(+)\end{array}$ & $\begin{array}{l}6 \\
5\end{array}$ & $\begin{array}{l}54.5 \\
45.5\end{array}$ & $\begin{array}{c}17 \\
4\end{array}$ & $\begin{array}{l}68.0 \\
16.0\end{array}$ & $\begin{array}{l}1 \\
0\end{array}$ & $\begin{array}{c}100.0 \\
0.0\end{array}$ & $\begin{array}{c}13 \\
0\end{array}$ & $\begin{array}{c}41.9 \\
0.0\end{array}$ & $\begin{array}{l}3 \\
1\end{array}$ & $\begin{array}{l}42.9 \\
14.3\end{array}$ \\
\hline
\end{tabular}

Table 3. Distribution of mucin secretion in relation to metastases in the lymph nodes

\begin{tabular}{|c|c|c|c|c|c|c|c|c|}
\hline \multirow{3}{*}{$\begin{array}{l}\text { Parameters } \\
\text { FUCOMUCINS }\end{array}$} & \multicolumn{8}{|c|}{ Metastases in the lymph nodes } \\
\hline & \multicolumn{2}{|c|}{$\begin{array}{c}\text { Without } \\
\text { deposits in } \\
\text { lymph nodes } \\
\end{array}$} & \multicolumn{2}{|c|}{$\begin{array}{l}\text { Deposits in } 1-3 \\
\text { lymph nodes }\end{array}$} & \multicolumn{2}{|c|}{$\begin{array}{l}\text { Deposits in } 4-6 \\
\text { lymph nodes }\end{array}$} & \multicolumn{2}{|c|}{$\begin{array}{c}\text { Deposits in } \\
\text { more than } 7 \\
\text { lymph nodes } \\
\end{array}$} \\
\hline & $n$ & $\%$ & $n$ & $\%$ & $\mathrm{n}$ & $\%$ & $\mathrm{n}$ & $\%$ \\
\hline No secretion & 25 & 69.4 & 8 & 36.4 & 1 & 12.5 & 2 & 22.2 \\
\hline $\begin{array}{l}+/- \\
(+)\end{array}$ & $\begin{array}{l}9 \\
2\end{array}$ & $\begin{array}{c}25.0 \\
5.6\end{array}$ & $\begin{array}{c}12 \\
2\end{array}$ & $\begin{array}{c}54.5 \\
9.1\end{array}$ & $\begin{array}{l}6 \\
1\end{array}$ & $\begin{array}{l}75.0 \\
12.5\end{array}$ & $\begin{array}{l}7 \\
0\end{array}$ & $\begin{array}{c}77.8 \\
0.0\end{array}$ \\
\hline SIALOMUCINS & $\mathrm{n}$ & $\%$ & $\mathrm{n}$ & $\%$ & $\mathrm{n}$ & $\%$ & $\mathrm{n}$ & $\%$ \\
\hline $\begin{array}{l}+/- \\
(+) \\
(++)\end{array}$ & $\begin{array}{c}7 \\
22 \\
7\end{array}$ & $\begin{array}{l}19.4 \\
61.1 \\
19.4\end{array}$ & $\begin{array}{c}2 \\
5 \\
15\end{array}$ & $\begin{array}{c}9.1 \\
22.7 \\
68.2\end{array}$ & $\begin{array}{l}0 \\
4 \\
4\end{array}$ & $\begin{array}{c}0.0 \\
50.0 \\
50.0\end{array}$ & $\begin{array}{l}0 \\
3 \\
6\end{array}$ & $\begin{array}{r}0.0 \\
33.3 \\
66.7\end{array}$ \\
\hline SULFOMUCINS & $\mathrm{n}$ & $\%$ & $\mathrm{n}$ & $\%$ & $\mathrm{n}$ & $\%$ & $\mathrm{n}$ & $\%$ \\
\hline No secretion & 4 & 11.1 & 11 & 50.0 & 3 & 37.5 & 7 & 77.8 \\
\hline $\begin{array}{l}+/- \\
(+)\end{array}$ & $\begin{array}{c}23 \\
9 \\
\end{array}$ & $\begin{array}{l}63.9 \\
25.0 \\
\end{array}$ & $\begin{array}{c}11 \\
0 \\
\end{array}$ & $\begin{array}{c}50.0 \\
0.0 \\
\end{array}$ & $\begin{array}{l}4 \\
1 \\
\end{array}$ & $\begin{array}{l}50.0 \\
12.5 \\
\end{array}$ & $\begin{array}{l}2 \\
0 \\
\end{array}$ & $\begin{array}{c}22.2 \\
0.0 \\
\end{array}$ \\
\hline
\end{tabular}


Table 4. Correlation analysis - interdependence of parameters - significance and degree of dependence

\begin{tabular}{|c|c|c|c|c|c|c|c|c|}
\hline & & Fucomucins & Sialomucins & Sulfomucins & $\begin{array}{c}\text { pT } \\
\text { stage }\end{array}$ & $\begin{array}{c}\mathrm{AC} \\
\text { stage }\end{array}$ & $\begin{array}{c}\text { Metastases } \\
\text { in the lymph } \\
\text { nodes }\end{array}$ & $\begin{array}{c}\text { Distant } \\
\text { metastases }\end{array}$ \\
\hline \multirow{2}{*}{ Fucomucins } & $\mathrm{cC}$ & 1.00 & $0.37 *$ & $-0.34 *$ & 0.22 & $0.43 *$ & $0.39 *$ & $0.33 *$ \\
\hline & $\mathrm{p}$ & . & 0.00 & 0.00 & 0.06 & 0.00 & 0.00 & 0.00 \\
\hline \multirow{2}{*}{ Sialomucins } & $\mathrm{cc}$ & $0.37 *$ & 1.00 & $-0.44 *$ & 0.35 & $0.47 *$ & $0.42 *$ & 0.23 \\
\hline & $\mathrm{p}$ & 0.00 & . & 0.00 & 0.00 & 0.00 & 0.00 & 0.04 \\
\hline \multirow{2}{*}{ Sulfomucins } & $\mathrm{cc}$ & $-0.34 *$ & $-0.44 *$ & 1.00 & $-0.45 *$ & $-0.50 *$ & $-0.50 *$ & -0.10 \\
\hline & $\mathrm{p}$ & 0.00 & 0.00 & . & 0.00 & 0.00 & 0.00 & 0.39 \\
\hline \multirow{2}{*}{$\begin{array}{c}\text { pT } \\
\text { stage }\end{array}$} & $\mathrm{cc}$ & 0.22 & $0.35 *$ & $-0.45 *$ & 1.00 & $0.60 *$ & $0.44 *$ & 0.17 \\
\hline & $\mathrm{p}$ & 0.06 & 0.00 & 0.00 & . & 0.00 & 0.00 & 0.13 \\
\hline \multirow{2}{*}{$\begin{array}{c}\text { AC } \\
\text { stage }\end{array}$} & $\mathrm{cc}$ & $0.43 *$ & $0.47 *$ & $-0.50 *$ & $0.60 *$ & 1.00 & $0.84 *$ & $0.54 *$ \\
\hline & $\mathrm{p}$ & 0.00 & 0.00 & 0.00 & 0.00 & . & 0.00 & 0.00 \\
\hline \multirow{2}{*}{$\begin{array}{c}\text { Metastases } \\
\text { in the lymph } \\
\text { nodes }\end{array}$} & $\mathrm{cc}$ & $0.39 *$ & $0.42 *$ & $-0.50 *$ & $0.44 *$ & $0.84 *$ & 1.00 & 0.23 \\
\hline & $\mathrm{p}$ & 0.00 & 0.00 & 0.00 & 0.00 & 0.00 & . & 0.05 \\
\hline \multirow{2}{*}{$\begin{array}{c}\text { Distant } \\
\text { metastases }\end{array}$} & $\mathrm{cc}$ & $0.33 *$ & $0.23 *$ & -0.10 & 0.17 & $0.54 *$ & 0.23 & 1.00 \\
\hline & $\mathrm{p}$ & 0.00 & 0.04 & 0.39 & 0.13 & 0.00 & 0.05 & . \\
\hline
\end{tabular}

* Significant $p<0.05$, cc - Spearman's correlation coefficient

Mucin secretion significantly differed only in relation to the metastases in the lymph nodes compared to the cases without the metastases, and a significant difference in the secretion of mucins between the cases with metastatic deposits and the cases without deposits was observed.

In a preliminary analysis, the cross-examination of the tested parameters indicated a high significance relationships in certain interrelated relationships. The correct measure of their connection was shown by a correlation analysis where the significance of that relationship was proved by the significance of the correlation coefficient, and the strength of the connection by its size. In Table 4, all the parameters that were the subject of the analysis in this study are shown through the correlation coefficient (cc) with its statistical significance (p).

A group of the cases without metastatic deposits was significantly different in the distribution of mucins in relation to the each individual group with a presence of deposits in the lymph nodes. (KruskalWallis test; $p<0.001$ to $p<0.007$ ). When the distribution of mucin secretion was considered within the groups without metastases, it was noticed that the absence of deposits in the lymph nodes was approaching the distribution of mucins according to the characteristics of normal colorectal tissue because it did not deviate much from the normal tissue.

The occurrence of metastases in the lymph nodes significantly changed the secretion of the mucins, increasing the intensity of fucomucins and sialomucins secretion with the increase in the number of affected nodes, while the secretion of sulphomucins was decreasing. However, these changes in the secretion of mucins did not show a significant difference between the groups with deposits. That is, the groups of lymph nodes with metastatic deposites did not significantly differ between themselves in relation to mucin expression (Kruskal-Wallis test; $\mathrm{p}=$ 0.119 to $p=0.755$ ).

Mucin secretion significantly differed only in relation to the metastases in the lymph nodes compared to the cases without the metastases, and a significant difference in the secretion of mucins between the cases with metastatic deposits and the cases without deposits was observed.

In a preliminary analysis, the cross-examination of the tested parameters indicated a high significance relationships in certain interrelated relationships. The correct measure of their connection was shown by a correlation analysis where the significance of that relationship was proved by the significance of the correlation coefficient, and the strength of the connection by its size. In Table 4, all the parameters that were the subject of the analysis in this study are shown through the correlation coefficient $(c c)$ with its statistical significance $(p)$.

Fucomucins were in a good, positive, and significant correlation with the Astler-Coller tumor stage ( $c c=0.43$ ), with the metastases in the lymph nodes ( $c c=0.39)$ and with the distant metastases ( $\mathrm{cc}=0.33$ ).

Sialomucins were in an even stronger, significant relationship with the Astler-Coller tumor stage ( $\mathrm{cc}=0.47$ ), with metastases in the lymph nodes (cc $=0.42$ ) and with the distant metastases ( $c c=0.23$ ). In contrast to neutral mucins, sialomucins were with the good, positive and significant correlation coefficient $(c c=0,35)$ associated with the pathological stage of the tumor.

Sulphomucins were with the good, significant, but negative correlation coefficients associated with 
the pathological stage of the tumor ( $c c=-0.45)$, with the Astler-Coller tumor stage classification (cc =0.50 ), and with lymph node metastases ( $c c=-0.50)$.

The secretions of neutral and weak acidic mucins were in a good and significant mutual relationship ( $c c=0.37$ ), only the secretion of sulphomucins was in the negative correlation with the other mucins ( $c c=-0.34, c c=-0.44)$.

\section{Discussion}

Mucus (phlegm) is a viscous colloidal substance produced by specialised goblet cells, and mucocytes of mucous or mixed seromucous glands. In the form of a thin layer, the water-insoluble gel covers the epithelium of the tubular organs and separates it from the lumen content. The mucus covers the mucous membranes that directly or indirectly come into contact with the outer environment, where it primarily has a protective role (13). Mucus contains water, antiseptic enzymes, immunoglobulins, inorganic salts, proteins and glycoprotein macromolecules-mucins (14). The most present component of mucus are the mucins that are responsible for the biochemical and biophysical properties of the mucus. They are divided into two large groups: membrane and secretory mucins (15).

Mucins represent a selective molecular barrier on the epithelial surface, provide protection of the cell surface and participate in morphogenetic cell transduction $(16,17)$. Based on the histochemical characteristics, they are divided into neutral fucomucins, weak acidic or sialomucins and strong acidicsulphomucins. Fucomucins contain N-acetyl derivates of hexosamine, D-galactose and L-fructose. Fukomucins do not have acid groups, so they are stained using PAS (Periodic Acid Schiff) method (12). Sialomucins contain hexosamine, glucuronic and sialic acid, and sulfomucins besides hexosamine and uronic acid also contain sulphate groups (11, $18,19)$. Specific molecular structure contributes to the specialised role of membrane mucins through which the information about the conditions in the external environment is transferred into the epithelial cells, and so they serve as receptors and sensors on the cell surface. They carry signals to extreme stimuli, thus leading to a coordinated cell response that includes differentiation, apoptosis, and secretion of specific products $(11,17)$.

The secretion of mucus glycoproteins is a slow but continuous process, which maintains a thin layer on the surface of the mucous membrane. Accelerated secretion occurs under the influence of various stimuli, physical or chemical factors. Mucins that are released from the cytoplasmic vesicles bound themselves to water and in the form of gel coat cover the mucous membrane (20).

In healthy colon mucosa the secretion of strong acidic sulphated mucins dominates, while neutral and weak acidic-sialomucins are mostly present in traces (21). In accordance with this, we have verified the pronounced and moderate secretion of strong acidic sulphomucins and a complete absence or trace secretion of neutral and weak acidicsialo- mucins in the non-tumor tissue, in the vicinity of the carcinomas of all of our patients.

The first significant aberrations of the mucin secretion have been observed in the second and third pT tumor stages, when the secretion of neutral and weak acidic mucins significantly increases, and the secretion of strong acidic sulphomucins significantly decreases. In relation to the Astler-Coller classification, a slight increase in the secretion of neutral mucins is observed already in B1 to B2 stages, while a significant increase in the secretion of fucomucins occurs in the C2 stage and continues in D stage with the occurence of moderate secretion. A slight increase in the secretion of weak acidic mucins has also been observed in the stages B1-B2, and then the secretion intensity increases linearly all the way to the hypesecretion of sialomucins, which dominates in the C2 stage, and especially in the D stage. In the C2 and D stages, a high significant absence of secretion (asecretion) or a trace secretion of strong acidicsulphomucins is observed. It has been observed in the literature that an increased quantity of sialomucins, besides in the tissue of the colorectal carcinoma, is also found in the transitional (transient) zone that surrounds the primary carcinoma. The same authors have claimed that the occurrence of sialomucins hypersecretion in this zone has been associated with poor prognosis and that the morphological and mucin components of the transitional zone are the prognostic factors for the progression of colorectal carcinoma (22).

In our research, we have observed that with the occurrence of metastases in the lymph nodes and the increase in the number of affected lymph nodes the secretion of neutral fucomucins and weak acidicsialomucins significantly increases, while the secretion of strong acidic-sulphomucins decreases. It is thought that increased sialinisation stimulates the migration of tumor cells through the extracellular matrix $(23,24)$, and it has been emphasized in numerous studies that the expression of sialomucins affects the processes of invasion and metastasis of the tumor (25).

Hypersecretion of sialomucins with the reduction of sulfomucins has been observed in adenomacarcinoma sequences in humans (26) and in the "aberrant cryptal focus" (ACF) in rats (27). If ACF is known to be the earliest known precancerous lesion, then it is clear that the occurrence of the hypersecretion of sialomucins is an early event in colorectal carcinogenesis.

Aberrations in the secretion of mucins simultaneously with the disorder of the protective function of mucus in the intestines also cause a disturbance of the signal transduction in which the mucin molecules are involved. This triggers the inflammatory processes in the intestinal mucous membrane and predisposes the development of the carcinoma. Chronic inflammation in the intestines leads to a change in glycosylation and causes deregulation of the mucins, and it is therefore thought that precisely this aberrant mucin expression represents a link between inflammation and carcinoma (28).

The mechanism by which the mucins participate in the pathogenesis of the carcinoma is not fully 
clear, but there is a presumption that the tumor growth area is hypoxic, acidic and full of proteases and other biologically active substances, and so the tumor tissue likely uses mucins for the configuration of the microenvironment during invasion, metastasis and growth under unfavorable conditions (18). Increased concentrations of mucin glycoproteins in serum are in correlation with an increased risk for tumor formation and poor prognosis, and therefore it is thought that excessive expression, inadequate expression, or the expression of aberrant mucin forms contributes to the pathogenesis of the carcinoma $(14,29)$.

In this study it has been noticed that mucin secretion does not depend on the demographic characteristics of the patients, on the localisation and on the macroscopic type of the tumor. The secretion of weak acidic sialomucins is associated with strong, significant and positive correlation coefficients with the pathological stage of the tumor, with the stages of the tumor according to the Astler-Coller classification and with metastases in the lymph nodes.
Sulphomucins are associated with significant, but negative correlation coefficients with the pathological stage of the tumor, with the stages of the tumor according to the Astler-Coller classification and with metastases in the lymph nodes.

\section{Conclusion}

In colorectal carcinoma, numerous alterations in the secretion of epithelial mucins occur, which are primarily manifested as a moderate to hypersecretion of sialomucins, trace or a moderate secretion of fucomucins and a trace or a complete asecretion of sulphomucins. Changes in the quality and quantity of mucins depend on the pathological stage of the tumor, on the Astler-Coller classification of the tumor stage, on the metastases in the lymph nodes and distant metastases, which indicates that the histochemical expression of mucins may be a useful prognostic indicator of colorectal carcinoma progression.

\section{References}

1. Hamilton SR, Bosman FT, Lyas M, Morreau $H$,

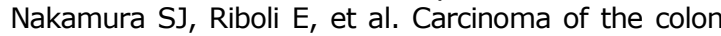
and rectum. In: Bosman FT, Carniero F, Hruban $\mathrm{RH}$, Theise D, editors. WHO Classification of Tumours of the Digestive System. 4th ed. Lyon: IARC; 2010. p. 132-46.

2. Torre LA, Bray F, Siegel RL, Ferlay J, Lortet-Tieulent J, Jemal A. Global cancerstatistics 2012.CA Cancer J Clin 2015; 65(2):87-108.[PubMed][CrossRef]

3. Ministry of Health of the Republic of Serbia. National Guidelines of Good Clinical Practice for the diagnostics and therapy of colon and rectal cancer. Beograd; 2012.

4. Siegel EM, Ulrich CM, Poole EM, Holmes RS, Jacobsen PB, Shibata D. The effects of obesity and obesityrelated conditions on colorectal cancer prognosis. Cancer Control 2010; 17(1):52-7. [PubMed][CrossRef]

5. Botteri E, Iodice S, Bagnardi V, Raimondi S, Lowenfels $A B$, Maisonneuve P. Smoking and colorectal cancer: a meta-analysis.JAMA 2008; 300(23):2765-78.

[PubMed][CrossRef]
6. Kattentidt-Mouravieva AA, den Heijer M, van Kessel I, Wagner A. How harmful is genetic testing for familial adenomatous polyposis (FAP) in young children; the parents' experience. Fam Cancer 2014; 13(3):391-9. [PubMed][CrossRef]

7. Neuman HB, Weiss JM, Leverson G, O'Connor ES, Greenblatt DY, Loconte NK, et al. Predictors of shortterm postoperative survival after elective colectomy in colon cancer patients $\geq 80$ years of age. Ann Surg Oncol 2013; 20(5):1427-35.[PubMed][CrossRef]

8. Steele SR, Park GE, Johnson EK, Martin MJ, Stojadinovic A, Maykel JA, et al. The impact of age on colorectal cancer incidence, treatment, and outcomes in an equal-access health care system. Dis Colon Rectum 2014; 57(3):303-10.[PubMed][CrossRef]

9. Kumar V, Abbas AK, Fausto N, Mitchell RN. Robin's Basics of Pathology. $8^{\text {th }}$ ed. Beograd: Datastatus; 2010.

10. Sharma D, Saxena NK, Vertino PM, Anania FA. Leptin promotes the proliferative response and invasiveness in human endometrial cancer cells by activating multiple signal-transduction pathways. Endocr Relat Cancer 2006; 13(2):629-40.[PubMed][CrossRef] 
11. Fukuda M. Roles of mucin-type O-glycans in cell athesion. Biochim Biophys Acta 2002; 1573: 394-405. [PubMed][CrossRef]

12. Jass JR, Walsh MD. Altered mucin expression in the gastrointestinal tract: a review. J Cell Mol Med 2001; 5:327-51.[PubMed][CrossRef]

13. Johansson ME, Hansson GC. Mucus and the goblet cell. Dig Dis 2013; 31(3-4):305-9. [PubMed][CrossRef]

14. Hollingsworth MA, Swanson BJ. Mucins in cancer: protection and control of the cell surface. Nat Rev Cancer 2004; 4:45-60.[PubMed][CrossRef]

15. Rachagani S, Torres MP, Moniaux N, Batra SK. Current status of mucins in the diagnosis and therapy of cancer. Biofactors 2009; 35:509-27.

[PubMed][CrossRef]

16. Jonckheere N, Van Seuningen I. The membranebound mucins: From cell signalling to transcriptional regulation and expression in epithelial cancers. Biochimie 2010; 92(1):1-11.[PubMed][CrossRef]

17. Carraway L, Ramsauer VP, Haq B, Carothers Carraway CA. Cell signaling through membrane mucins. Bioessays 2003; 25(1):66-71.[PubMed][CrossRef]

18. Inagaki $Y, X u H$, Nakata $M$, Seyama $Y$, Hasegawa $K$, Sugawara $Y$, et al. Clinicopathology of sialomucin: MUC1, particularly KL-6 mucin, in gastrointestinal, heaptic and pancreatic cancers. Biosci Trends 2009; 3(6):220-32.[PubMed]

19. Barchi JJ Jr. Mucin-type glycopeptide structure in solution: past, present, and future. Biopolymers 2013; 99(10):713-23.[PubMed][CrossRef]

20. Gendler SJ, Spicer AP. Epithelial mucin genes. Annu Rev Physiol 1995; 57:607-34.[PubMed][CrossRef]

21. Matsushita Y, Yamamoto N, Shirahama H, Tanaka S, Yonezawa S, Yamori T, et al. Expression of sulfomucins in normal mucosae, colorectal adenocarcinomas, and metastases. Jpn J Cancer Res 1995; 86(11): 1060-7.[PubMed][CrossRef]

22. Tamai O, Miyazato $H$, Shiraishi M, Kusano T, Muto Y. Morphologic and mucin histochemical analysis of tran- sitional zones in advanced ulcerated colorectal carcinomas: potential prognostic indicators. J Surg Oncol 1998; 67(2):85-9.[PubMed][CrossRef]

23. Schultz MJ, Swindall AF, Bellis SL. Regulation of the metastatic cell phenotype by sialylated glycans. Cancer Metastasis Rev 2012; 31(3-4):501-18. [PubMed][CrossRef]

24. Seales EC, Jurado GA, Brunson BA, Wakefield JK, Frost AR, Bellis SL. Hypersialylation of beta1 integrins, observed in colon adenocarcinoma, may contribute to cancer progression by up-regulating cell motility. Cancer Research 2005; 65: 4645-52. [PubMed][CrossRef]

25. Yu CJ, Shew JY, Shun CT, Lin HT, Kuo SH, Luh KT, et al. Quantitative analysis of mRNA encoding MUC1, MUC2, and MUC5AC genes: a correlation between specific mucin gene expression and sialomucin expression in non-small cell lung cancer. Am J Respir Cell Mol Biol 1998; 18(5):643-52.[PubMed][CrossRef]

26. Corfield AP, Myerscough N, Warren BF, Durdey P, Paraskeva C, Schauer R. Reduction of sialic acid Oacetylation in human colonic mucins in the adenomacarcinoma sequence. Glycoconj J1999; 16:307-17. [PubMed][CrossRef]

27. Uchida K, Kado S, Ando M, Nagata Y, Ando M, Takagi $A$, et al. A mucinous histochemical study of malignancy of aberrant crypt foci (ACF) in rat colon. J Vet Med Sci 2001; 63(2): 145-9.[CrossRef]

28. Sheng $\mathrm{YH}$, Hasnain SZ, Florin TH, McGuckin MA. Mucins in inflammatory bowel diseases and colorectal cancer. J Gastroenterol Hepatol 2012; 27(1):28-38. [PubMed][CrossRef]

29. Saldova R, Piccard H, Pérez-Garay M, Harvey DJ, Struwe WB, Galligan MC, et al. Increase in sialylation and branching in the mouse serum N-glycome correlates with inflammation and ovarian tumor progression. PLoS One 2013; 8(8):e71159. [PubMed][CrossRef] 


\title{
KLINIČKI ZNAČAJ HISTOHEMIJSKE EKSPRESIJE MUCINA U KOLOREKTALNOM ADENOKARCINOMU
}

\author{
Nina S. Jančić1, Janko T. Žujović ${ }^{2}$, Ivan B.Rančić1, Miljan S. Krstić3, \\ Filip C. Vukmirovićt, Velimir S. Miloševićs
}

\author{
${ }^{1}$ Univerzitet u Nišu, Medicinski fakultet, Niš, Srbija \\ ${ }^{2}$ Centar za abdominalnu hirurgiju, Klinički centar Crne Gore, Podgorica, Crna Gora \\ ${ }^{3}$ Univerzitet u Nišu, Medicinski fakultet, Institut za Patologiju, Niš,Srbija \\ ${ }^{4}$ Centar za patologuju, Klinički centar Crne Gore, Podgorica, Crna Gora \\ ${ }^{5}$ Klinika za gastroenterologiju i hepatologiju, Klinički centar Crne Gore, Podgorica,Crna Gora
}

Kontakt: Velimir S. Milošević

Ljubljanska 1, 20000 Podgorica, Crna Gora

E-mail: vejja@t-com.me

Kolorektalni karcinom je najučestaliji maligni tumor gastrointestinalnog trakta. Tokom kolorektalne karcinogeneze, osim nekontrolisane proliferacije ćelija i ubrzane angiogeneze nastaju i alteracije u strukturi i/ili količini epitelnih mucina, pa je cilj našeg rada ispitivanje histohemijske ekspresije mucina u odnosu na klinčke karakteristike kolorektalnog karcinoma.

Za ispitivanje je korišćen biopsijski material 75 bolesnika operisanih od kolorektalnog karcinoma, koji je rutinski obrađivan i kalupljen u parafin. Na rezovima debljine od $3 \mu \mathrm{m}$ do $4 \mu \mathrm{m}$, primenjene su rutinska H\&E i histohemijske AB-PAS pH 2,5 i HID-AB metode. Za statističku analizu korišćen je statistički programski paket SPSS (verzija 13).

U kolorektalnom karcinomu nastaju alteracije mucina koje se manifestuju kao sekrecija u tragu do umerene sekrecije fukomucina, umerene do hipersekrecije sijalomucina i sekrecije u tragu do potpune asekrecije sulfomucina. Sekrecija fukomucina i sijalomucina je jakim, signifikantnim i pozitivnim koeficijentima korelacije povezana sa stadijumima tumora po AstlerColler klasifikaciji, sa metastazama u limfnim žlezdama i sa udaljenim metastazama. Za razliku od fukomucina, sijalomucini su jakim, pozitivnim, značajnim korelacionim koeficijentom povezani i sa patološkim stadijumom tumora. Sulfomucini su signifikantnim, malim negativnim koeficijentima korelacije povezani sa patološkim stadijumom tumora, sa stadijumima tumora po Astler-Coller klasifikacijii i sa metastazama u limfnim žlezdama. Sekrecije fukomucina i sijalomucina u dobroj su i značanoj uzajamnoj povezanosti, jedino je sekrecija sulfomucina u negativnoj korelaciji prema ostalim mucinima.

Histohemijska ekspresija mucina može biti koristan prognostički pokazatelj progresije kolorektaknog karcinoma.

Acta Medica Medianae 2019;58(3):49-59.

Ključne reči: kolorektalni karcinom, epitelni mucini, histohemija 